\title{
Assessment of electrochemotherapy effects on the development of Ehrlich solid tumor in swiss mice using a novel electroporator device
}

\author{
[Avaliação dos efeitos da eletroquimioterapia sobre o desenvolvimento do tumor sólido de Ehrlich \\ em camundongos Swiss utilizando um novo eletroporador] \\ R.M.C. Cunha ${ }^{1}$, G.E. Lavalle $^{1}$, D.C. Reis ${ }^{2}$, R.S. Horta ${ }^{3}$, S.V. Teixeira ${ }^{2}$, \\ J.A. Ramirez ${ }^{4}$, R.B. Araújo $^{1}$ \\ ${ }^{1}$ Escola de Veterinária - Universidade Federal de Minas Gerais - Belo Horizonte, MG \\ ${ }^{2}$ Instituto de Ciências Biológicas - Universidade Federal de Minas Gerais - Belo Horizonte, MG \\ ${ }^{3}$ Universidade Vila Velha - UVV - Vila Velha, ES \\ ${ }^{4}$ Escola de Engenharia - Universidade Federal de Minas Gerais - Belo Horizonte, MG
}

\begin{abstract}
Electrochemotherapy is a local anticancer treatment in which non-permeant chemotherapeutic drugs are associated with electric pulses of well-established parameters. The electric pulses cause pores to open on the plasma membrane and facilitate drug transport, enhancing cytotoxicity and reducing side effects. Assessment of electrochemotherapy effects on Ehrlich solid tumor development in this work aims to evaluate in vivo usage of the electroporator device developed by the Department of Electrical Engineering of Engineering School of UFMG. Therefore, 40 Swiss mice were inoculated with Ehrlich tumor cells, and developed the tumor in solid form. After 21 days, mice were subjected to specific treatment protocols (control, bleomycin, electric pulses and electrochemotherapy); 17 days later they were euthanized and the tumors collected for histopathology analysis. Electrochemotherapy induced discrete weight loss and an inflammatory response in the tumor, which was not seen on the other treatment groups. Bleomycin alone induced necrosis. Both groups showed lower cellular proliferation rates. From this study, it was concluded that the animals tolerated electrochemotherapy treatment under anesthesia and the electroporator device developed by the Engineering School of UFMG was adequate when used in an electrochemotherapy protocol.
\end{abstract}

Keywords: mouse, oncology, electrochemotherapy, experimental tumor

\section{RESUMO}

Eletroquimioterapia é uma modalidade de tratamento local contra o câncer em que a administração de quimioterápicos não penetrantes à membrana plasmática é associada à aplicação de pulsos elétricos com parâmetros bem estabelecidos, que abrem poros na membrana plasmática e facilitam a entrada desses fármacos nas células, aumentando sua citotoxicidade e reduzindo efeitos colaterais. A avaliação dos efeitos da eletroquimioterapia sobre o desenvolvimento do tumor sólido de Ehrlich em camundongos Swiss neste trabalho teve como objetivo testar o uso in vivo do aparelho eletroporador desenvolvido pelo Departamento de Engenharia Elétrica da Escola de Engenharia da UFMG. Para tanto, foram utilizados 40 camundongos fêmeas da linhagem Swiss, nos quais foram inoculadas células de tumor de Ehrlich, para o desenvolvimento do tumor na forma sólida. Após 21 dias, os camundongos foram submetidos ao protocolo de tratamento específico (controle, bleomicina, pulsos elétricos e eletroquimioterapia); 17 dias depois foram eutanasiados e seus tumores coletados para análise histopatológica e imuno-histoquímica. A eletroquimioterapia induziu perda de peso discreta e uma resposta inflamatória no tumor que não foi observada nos outros grupos. O grupo bleomicina apresentou maior porcentagem de necrose. Ambos os grupos apresentaram menor indice de proliferação celular. Com este estudo, pode-se concluir que o tratamento sob anestesia foi bem tolerado pelos animais e que o aparelho eletroporador desenvolvido pela Escola de Engenharia da UFMG é adequado para utilização em um protocolo de eletroquimioterapia.

Palavras-chave: camundongo, oncologia, eletroquimioterapia, tumor experimental

Recebido em 19 de maio de 2016

Aceito em 8 de setembro de 2016

E-mail: rubiamcc@gmail.com 


\section{INTRODUCTION}

Electrochemotherapy is chemotherapy associated with tumor electroporation to enhance cell drug uptake (Sersa et al., 2003). Electroporation is the increase in membrane permeability due to applied external electric pulses (Silva, 2011). Electroporation facilitates drug transport through the cell membrane only for poorly or nonpermeant molecules. Therefore, potential electrochemotherapy drugs must be cytotoxic hydrophilic molecules with limited membrane transport systems (Sersa et al., 2006; Sersa et al., 2008).

Electroporation is the result of a cell membrane reorganization (originating "electropores") due to an electric field pulse. This event is located on the cell surface, and is induced when the local field strength exceeds a critical threshold. Then, polar molecules can cross the cell membrane (Cemazar et al., 2008). The following parameters were established for electroporation maximum efficacy, without inducing irreversible permeabilization: eight consecutive square wave electric pulses, uni or bipolar, $100 \mu$ seconds $(\mu \mathrm{s})$ duration, 1 hertz $(\mathrm{Hz})$ or $5 \mathrm{kHz}$ frequency, and 1000 to $1300 \mathrm{~V} / \mathrm{cm}$ tension (Mir, 2006; Sersa et al., 2006; Larkin et al., 2007; Cemazar et al., 2008). Because exogenous electric field pulse parameters influence electroporation efficacy, it is important to develop electroporator devices to control pulse parameters (Silva, 2011).

Bleomycin is a hydrosoluble antibiotic antineoplastic drug that has been used in a variety of human and canine tumors. It is extremely toxic once inside the cell, but this elevated intrinsic cytotoxicity is restricted due to bleomycin's inability to diffuse through the plasma membrane (Pron et al., 1993; Mir et al., 1996; Gothelf et al., 2003). Electrochemotherapy enhances bleomycin intracellular concentration 300 to 700 times, with a consequent cytotoxicity elevation of thousands of times (Larkin et al., 2007).

Bleomycin may induce acute or late side effects, especially when combined with other agents in systemic chemotherapy or with radiotherapy (Tozon et al., 2005). The main late bleomycin side effect is pulmonary fibrosis, which may occur with a cumulative dose higher than 400,000 IU in humans (Lanore and Delprat, 2004). Nevertheless, smaller cumulative doses are necessary to achieve objective responses when electroporation is used (Tozon et al., 2005). Bleomycin doses with none or minimal antitumor efficacy had approximately $80 \%$ of objective responses when used in electrochemotherapy (Cemazar et al., 2008).

Bleomycin route of administration is intravenous (IV) or intratumoral (IT) (Cemazar et al., 2008). Interval between drug administration and electric pulse delivery is important because a sufficient amount of drug must be present around the tumor when pulses are applied (Sersa et al., 2006; Cemazar et al., 2008). When bleomycin is administered systemically (IV), pulses should be applied during the drug's pharmacokinetic peak, which happens between 8 and 28 minutes in humans. However, for intratumoral administration, pulses should be applied 1 to 10 minutes after drug delivery (Sersa et al., 2008).

Electrochemotherapy is easy and safe to perform. The requirements are an adequate room for patient preparation and treatment and an electroporator device with different types of electrodes to use in different sizes of nodules (Sersa et al., 2003). Single or multiple nodules are treated with systemic anesthesia (Mir et al., 2006).

There are few options of electroporator devices commercially available to use in vivo in Brazil. Therefore, a partnership was established between Veterinary School and Engineering School of the Universidade Federal de Minas Gerais (UFMG) to develop such a device. Once built and tested, the electroporator device could be used to treat patients with spontaneous neoplasms, consisting in another therapeutic option for veterinary oncology in Brazil.

The objectives of this study were to test the in vivo usage of the electroporator device developed by the Department of Electrical Engineering of the Engineering School of UFMG and to assess the effects of electrochemotherapy on the development of Ehrlich solid tumor in Swiss mice.

\section{MATERIALS AND METHODS}

The study was conducted in accordance with ethical principles for the use of animals in animal testing and after approval by the Ethics 
Committee on Animal Use (CEUA/UFMG) under protocol number (206/2014).

An electroporator device was developed by the Department of Electrical Engineering of Engineering School of Universidade Federal de Minas Gerais. A switching system controlled by microcontrollers was used to deliver voltage pulses with maximum amplitude of $1000 \mathrm{~V}$ to the bio burden. The switching unit used was MOSFET K119, which tolerates voltages of up to $1000 \mathrm{~V}$ and minimum switching times of 100 ns. Data presentation was through a microcomputer monitor used to control the acquisition board. To produce a compact high voltage source, a three-stage capacitive multiplier circuit was used. Bipolar switching was achieved with an $\mathrm{H}$ bridge circuit. Electric pulses were delivered through electrodes constituted of three parts: connectors, handhold and needles (Santos, 2014).

Forty female Swiss mice, 45 days old, were housed in plastic boxes (5 animals/box) and given the same commercial diet and water $a d$ libitum. Mice were subjected to a regime of 12 hours with light and 12 hours without light. Animals were distributed in four groups and subdivided into two groups of five animals, and were inoculated with Ehrlich tumor cells on the left flank. After 21 days, when tumors reached approximately $0.94 \mathrm{~cm}^{3}$, mice were subjected to each specific treatment protocol.

Bleomycin sulphate (Tecnomicina ${ }^{\circledR}$, Zodiac Produtos Farmacêuticos S.A., Pindamonhangaba, São Paulo, Brasil) was obtained in powder and diluted with distilled water (1000 IU in $1.0 \mathrm{~mL})$. Bleomycin solution was administered directly to the nodules, IT.

Electric pulses were administered through a needle electrode (two parallel rows of stainless steel needles of $1 \mathrm{~mm}$ diameter and $8 \mathrm{~mm}$ length, and internal distance between rows of $5 \mathrm{~mm}$ ) (Esope, 2003). Eight square wave pulses $(4+4)$ of $100 \mu$ seconds duration each, $1300 \mathrm{~V} / \mathrm{cm}$ amplitude and $5 \mathrm{KHz}$ frequency were generated by the novel developed electroporator device (Figure 4).

All mice were subjected to an anesthetic protocol consisting of morphine (Dimorf®, Cristália, São Paulo, São Paulo, Brasil) (2 mg/kg), midazolam maleate (Midazolam, Medley Indústria Farmacêutica Ltda., Campinas, São Paulo, Brasil) (3 $\mathrm{mg} / \mathrm{kg}$ ) and ketamine (Ketamin ${ }^{\circledR}$, Cristália, Itapira, São Paulo, Brasil) $(20 \mathrm{mg} / \mathrm{kg})$ on the same syringe intramuscularly, immediately before being subjected to their respective treatment. Mice were injected with 0.2-0.6 mL of saline or bleomycin solution (1000 $\mathrm{IU} / \mathrm{mL}$ ) IT, according to their respective tumor size. Group 1 (Control) - Mice were injected with saline. Needle electrode was inserted in the nodules, but pulses were not discharged. Group 2 (Bleomycin) - Mice were injected with bleomycin solution. Needle electrode was inserted in the nodules, but pulses were not discharged. Group 3 (Electric pulses) - Mice were injected with saline. Groups of 8 square wave pulses divided in two sequences of 4 pulses were applied. The second 4-pulse sequence was applied perpendicular to the first. Pulse groups were applied as necessary to electroporate the whole nodule. Group 4 (Electrochemotherapy) Mice were injected with bleomycin solution. Groups of pulses were applies exactly as for group 3. Electric pulses were applied immediately after bleomycin injection.

During the experimental period, tumor growth and mice weight were assessed. Tumor volume $(\Delta \mathrm{V})$ was monitored for a period of seventeen days for all four groups after their respective treatments, due to the high growing rate of Ehrlich tumor model. Tumor growth curve was obtained from the formula $V=a b^{2} \pi / 6$, in which $V$ is tumor volume, $a$ is the largest diameter, and $b$ is the diameter perpendicular to $a$ (Elbialy et al., 2010; Elbialy e Mady, 2015). Measurements were made with a caliper every two days after tumor inoculation. After follow-up period, animals were euthanized and necropsied. Tumors were collected for histopathologic analysis.

Tumor fragments were fixed in $10 \%$ neutral phosphate-buffered formalin. The tissues were dehydrated gradually in ethanol, embedded in paraffin, cut into $4 \mu \mathrm{m}$ sections, stained with hematoxylin and eosin (HE), and examined under light microscopy for histomorphological and histomorphometric analysis. For the histomorphometric analysis, the percentage area of neoplasia, necrosis, inflammation (angiogenesis, hemorrhage, and edema), and normal tissue in 15 histologic fields was calculated, in accordance with Pereira et al. 
(2013). Histologic images were obtained from a capture system with SPOT Basic ${ }^{\circledR}$ 3.4.5 microcamera adapted to an Olympus microscope (BX-40). Images were analyzed with 7.468 Corel Draw ${ }^{\circledR}$ software.

For immunohistochemistry analysis, $4 \mu \mathrm{m}$ sections were obtained from the paraffin blocks, transferred into gelatin-coated slides and followed by deparaffinization and rehydration. All phases of slide preparation were accompanied with a positive control defined by the antibody folder and a negative control (absence of the primary antibody).

Primary antibody anti-cdc47 (clone 47DC141, Neomarkers, 1:300) was used to identify proliferating neoplastic cells. Antibody was diluted in IHC diluent solution (Novocastra Laboratories, Newcastle, Inglaterra) and incubated for 1 hour in humidity chamber. Advance $^{\mathrm{TM}}$ HRP (Dako, Carpinteria, EUA) polymer was used for immunohistochemistry signal amplification and 3,3, liquid diaminobenzidine (DAB) chromogenic solution (Dako, Carpinteria, EUA) was used for revelation. Slides were counterstained with Harris hematoxylin. The index for this marker was obtained from estimate percentage of positive cells in 500 tumor cells. Count was done in 40x objective and 10x ocular fields, according with Souza et al. (2011).

All data were checked for normality. Statistical significance between groups was performed by

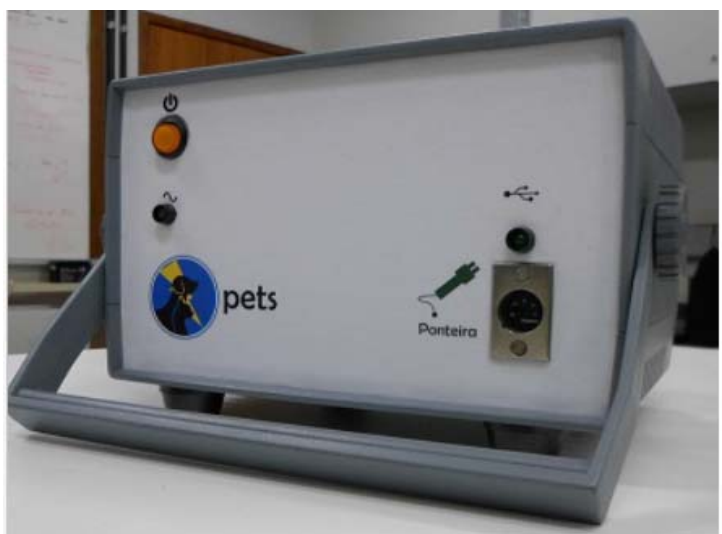

Figure 1. Electroporator device developed by the Department of Electrical Engineering of Engineering School of UFMG to use in in vivo electrochemotherapy. the application of one-way analysis of variance ANOVA followed by Fisher test and post-hoc Tukey test when data were normally distributed. Kruskal-Wallis tests were used when data were not normally distributed. The difference was reliable with $\mathrm{P}<0.05$.

Pearson correlation was used to test and measure the association between data obtained in histomorphometry and $\mathrm{Cdc} 47$ expression. Significant correlations were considered strong when there were more than $49 \%$ of the studied population $(\mathrm{r}>0.07)$, moderate when there were 9 to $49 \%(0.3<\mathrm{r}<0.07)$ and weak when there were less than $9 \%$ of the studied population $(r<0.3)$.

\section{RESULTS AND DISCUSSION}

The novel electroporator device, developed by the Department of Electrical Engineering of Engineering School of UFMG (Figure 1), allows individual programming of some pulse parameters, such as amplitude, frequency and wave polarity. The device allows in vivo electroporation with a simple and easy humanmachine interface (Figure 2). The parallel needle electrode was chosen because the nodules were small and subcutaneous, in accordance to Marty et al. (2006).

Pulses produced by the novel device matched the time and amplitude pre-requisites desired, as shown in Figure 3.

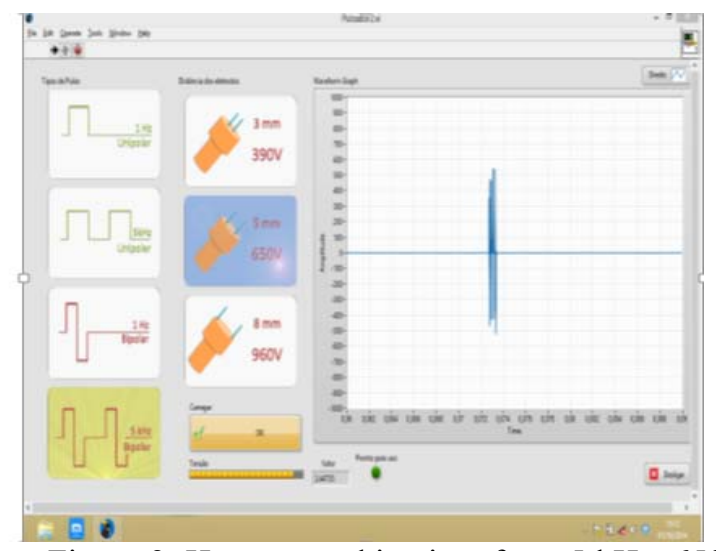

Figure 2. Human-machine interface. $5 \mathrm{kHz}, 650$ $\mathrm{V}$, and bipolar square wave pulses visualized in the synoptic panel of the software developed by the Engineering School of UFMG to use with the electroporator device. 


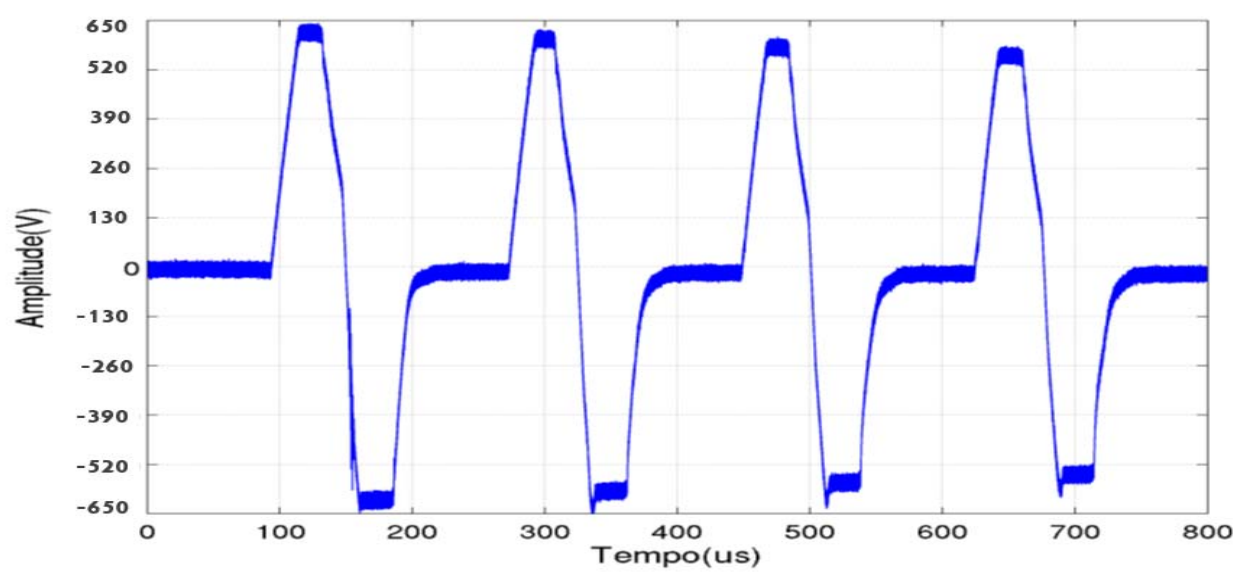

Figure 3. Bipolar square wave $100 \mu$ seconds duration, $5 \mathrm{kHz}$ frequency and $650 \mathrm{~V}$ amplitude pulses applied during treatment in electric pulses and electrochemotherapy groups. Pulses generated by the electroporator device developed by Engineering School of UFMG.

Mice weight was statistically lower for the electrochemotherapy group (average $5 \%$ body weight loss) when compared to the other groups (Table 1). This weight loss was smaller than observed by Sersa et al. (1994), and no deaths were reported in the present study. Thus, treatment was well tolerated and with minimal side effects.

Tumor weight was statistically higher for the electric pulses group when compared to the other groups (Table 2). Tumor growth in the electric pulses group was not observed in other similar studies, where there was no change in tumor growth or there was a slight reduction in tumor growth in tumors subjected only to electric pulses with similar parameters (Sersa et al., 1994; Sersa et al., 2006; Sersa et al., 2008). Therefore, other studies are necessary to assess possible interactions between electric pulses and neoplasia as a promoting agent.

There was a higher percentage of inflammation in the electrochemotherapy group and a higher percentage of necrosis in the bleomycin group in the histopathologic study (Figure 4 and Figure 5).

Table 1. Mice weight average every 4 days for each treatment group. Treatment day is indicated with an asterisk

\begin{tabular}{lccccccccccc}
\hline \multicolumn{1}{c}{$\begin{array}{c}\text { Days } \\
\text { Groups }\end{array}$} & 1 & 4 & 8 & 12 & 16 & $20 *$ & 24 & 28 & 32 & 36 & 38 \\
\hline Control & 24,8 & 26,2 & 27,4 & 29,0 & 30,0 & 29,9 & 30,9 & 32,0 & 31,9 & 33,0 & 33,5 \\
Bleomycin & 24,9 & 25,4 & 27,8 & 29,8 & 30,1 & 30,7 & 30,9 & 31,2 & 32,2 & 32,7 & 32,5 \\
Electric pulses & 24,4 & 26,5 & 27,7 & 29,0 & 29,0 & 30,3 & 30,7 & 31,4 & 32,4 & 32,9 & 33,3 \\
Electrochemotherapy & 24,6 & 26,4 & 27,0 & 28,9 & 28,9 & 29,5 & 29,3 & 29,9 & 30,6 & 31,0 & 31,8 \\
\hline
\end{tabular}

Table 2. Average tumor weight and tumor growth inhibition percentage for Ehrlich solid tumor after each treatment

\begin{tabular}{lll}
\hline Group & $\begin{array}{l}\text { Final average tumor weight } \\
(\mathrm{mg})\end{array}$ & $\begin{array}{l}\text { Tumor growth inhibition } \\
\text { percentage }\end{array}$ \\
\hline Control & 1764 & $0 \%$ \\
Bleomycin & 1485 & $15,8 \%$ \\
Electric pulses & 3657,2 & $-107,3 \%$ \\
Electrochemotherapy & 1070,3 & $39,3 \%$ \\
\hline
\end{tabular}




\section{Cunha et al.}
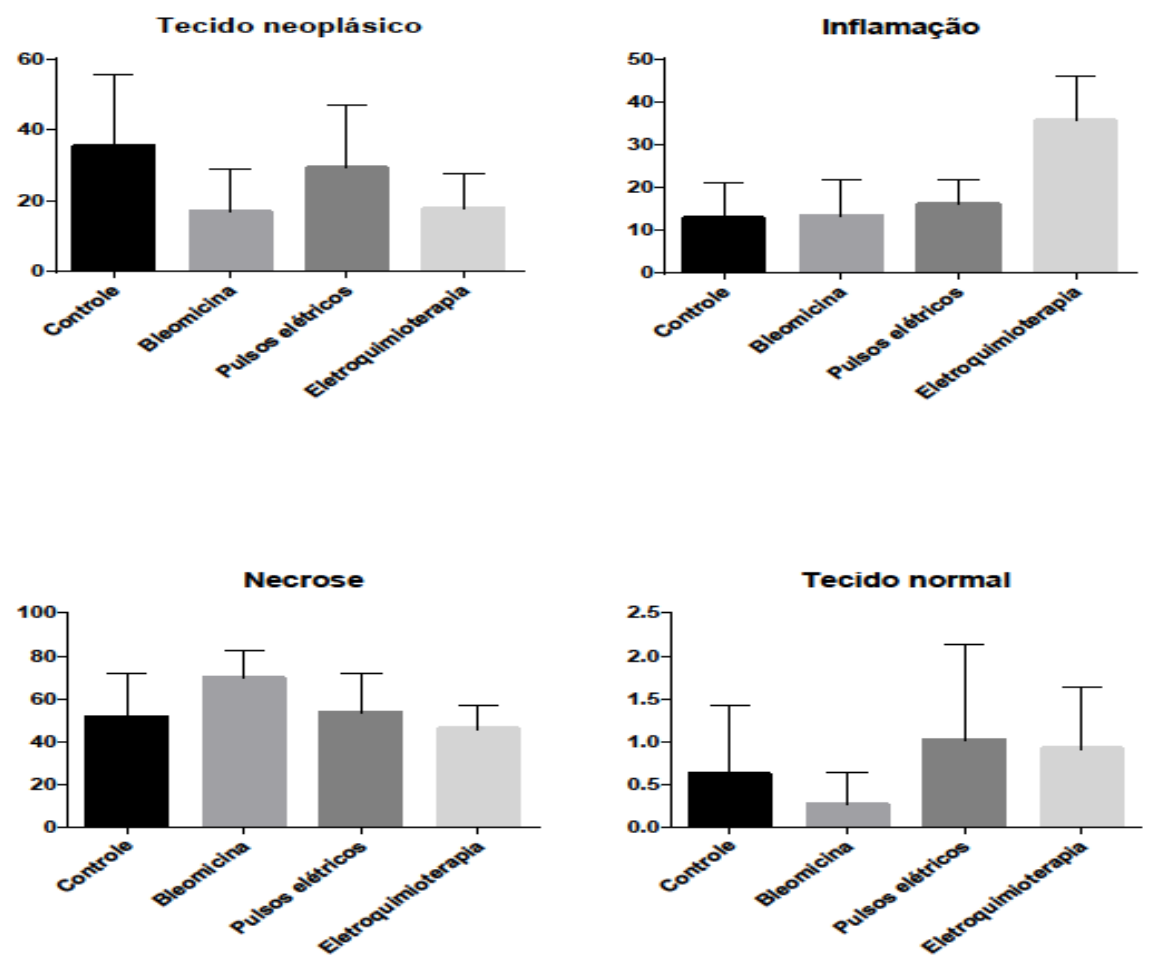

Figure 4. Graphic representation with mean and standard deviation for histomorphological and histomorphometric analysis (neoplastic tissue, inflammation, necrosis and normal tissue percentages) of Ehrlich solid tumor in Swiss mice for each treatment group (Control, Bleomycin, Electric pulses and Electrochemotherapy).
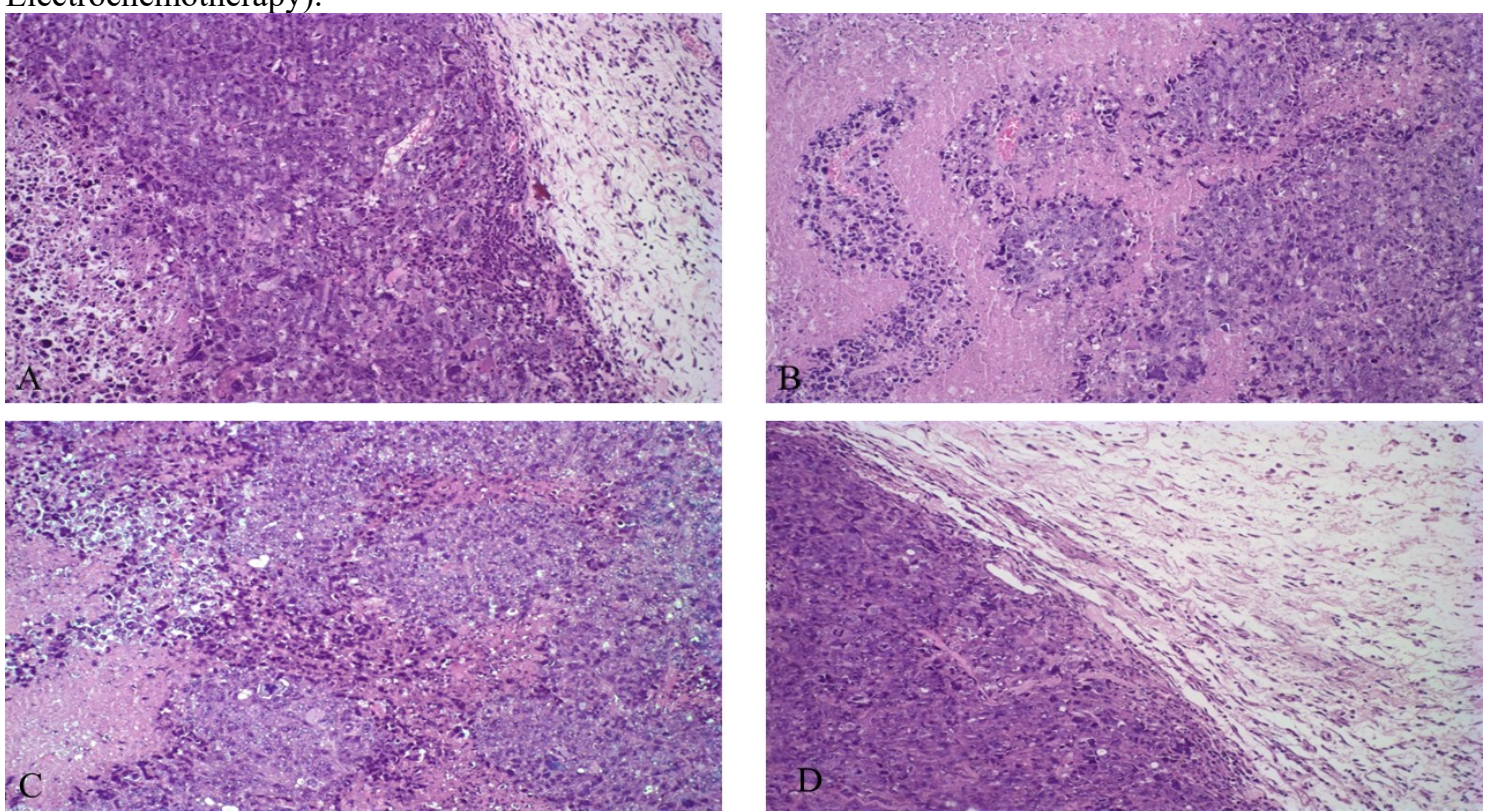

Figure 5. Photomicrography of Ehrlich solid tumor in Swiss mice in (A) Control group, (B) Bleomycin group, (C) Electric pulses group, and (D) Electrochemotherapy group. A larger necrosis area in (B) and a larger inflammation area (D) may be seen (H.E. 20x). 
Bleomycin was administered intratumorally, and not intravenously through the tail vein as previously reported (Sersa et al., 1994). This procedure modification may have interfered with anti-tumor response, because the tumor is solid and difficult to perfuse, with drug extravasation. Technical difficulty of performing a venous access in Swiss mice due to their small size influenced the choice of such route of administration.

Bleomycin lung infusion is the experimental model most frequently used to investigate cellular and biochemical mechanisms relevant to pulmonary fibrosis pathogenesis. A single dose of $25 \mu \mathrm{L}$ with $0.125 \mathrm{U}$ of bleomycin diluted in PBS may be intratraqueally instilled to cause pulmonary fibrosis according to Russo et al. (2009). In the study conducted by Russo et al. (2011), intratraqueal infusion of bleomycin was associated with significant clinical disease, seen as weight changes and death rates of $60 \%$ by Day 16. Bleomycin dose selected for this experiment was 200 to $600 \mathrm{IU}$ (0.2 to $0.6 \mathrm{U}$ ) per animal, according to tumor volume. This bleomycin dose did not induce animal mortality and did not affect body weight of the animals in the Bleomycin group when compared with animals in Control group, in accordance with Sersa et al. (1994; 2008).

Host immune system is involved in anti-tumor response and, therefore, contributes to cytotoxic therapy efficacy, killing viable remaining tumor cells as described by Sersa et al. (1997). The study conducted by Sersa et al. (1997) showed that immune response is essential for electrochemotherapy effects on the complete eradication of tumor cells when studying immunocompetent and immunocompromised mice. This is believed to be related to antigen release from destroyed cells after electrochemotherapy, which would activate immune cells within the tumor (Miklavcic et al., 2014). Ehrlich tumor cells loose class II Major Histocompatibility Complex (MHC) antigens during malignant transformation, so this tumor is considered weakly immunogenic (Carry et al., 1979; Ferreira, 2006). In the present study, antitumor response in the group treated with electrochemotherapy may have been inferior to other similar studies due to bleomycin route of administration and to the low immunogenicity of the cell lineage. Nevertheless, it was possible to observe that electrochemotherapy induced an inflammatory response that was not seen on the other groups.

Bleomycin and Electrochemotherapy groups showed a lower proliferation percentage when compared to the other groups using $\mathrm{Cdc} 47$ immunohistochemistry (Figure 6 and Figure 7). There was a moderate correlation between tumor proliferation percentage using $\mathrm{Cdc} 47$ and neoplastic tissue percentage $(\mathrm{P}=0.08$ and $\mathrm{rp}=$ 0.443). This result was expected because the lower the neoplastic tissue percentage, the lower the proliferation rate of a tumor.

\section{Cdc47}

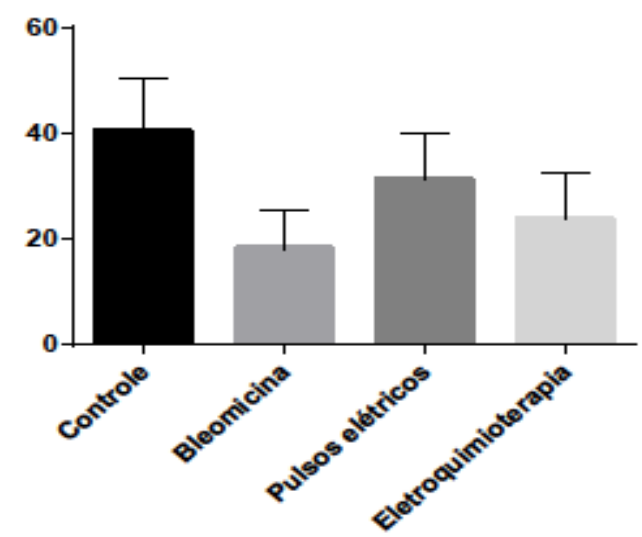

Figure 6. Graphic representation with mean and standard deviation for average proliferation percentage assessed with Cdc47 immunohistochemistry of Ehrlich solid tumor in Swiss mice for each treatment group (Control, Bleomycin, Electric pulses and Electrochemotherapy). 


\section{Cunha et al.}
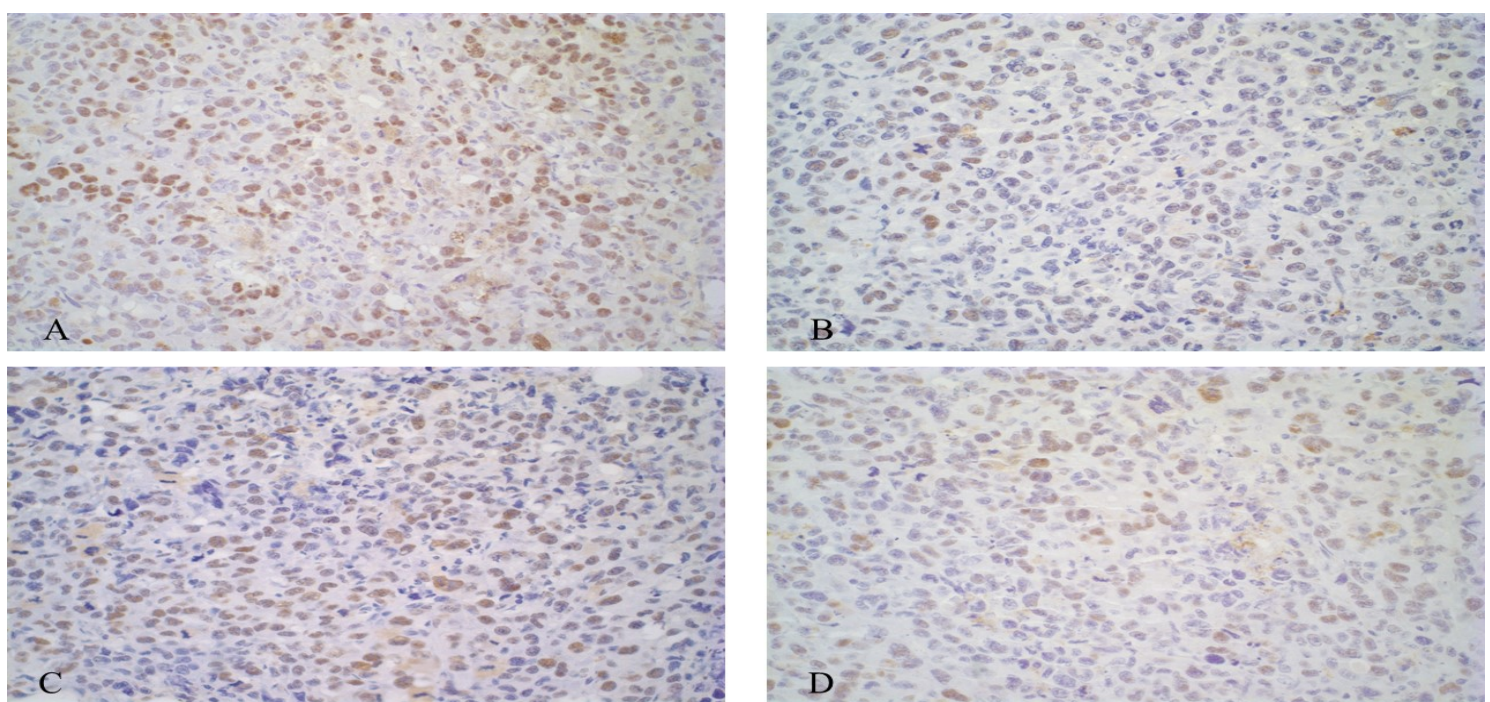

Figure 7. Photomicrography of immunohistochemistry expression of anti-cdc47 antibody of Ehrlich solid tumor in Swiss mice for each group: (A) Control, (B), Bleomycin, (C), Electric pulses and, (D) Electrochemotherapy. Marking is nuclear and more intense in (A and C, 40x) and less intense in (B and $\mathrm{D}, 40 \mathrm{x})$.

Bleomycin is a hydrosoluble polar drug that does not diffuse through the plasma membrane; thus, bleomycin anti-tumor effect is limited due to its low cell uptake (Pron et al., 1993; Sersa et al., 1994). Using DC-3F cells, Pron et al. (1993) studied a plasma membrane protein that binds to bleomycin. This protein limits bleomycin internalization mechanism. The number of bleomycin molecules that adhere to the cell depends on the number of protein molecules present on the membrane, and this number varied with the number of in vitro passages. According to Mir et al. (1996), DC-3F hamster mutant fibroblasts with varying amounts of this protein in their surface showed a bleomycin sensibility that was correlated with the abundance of this protein in the cell surface. This indicates that the number of bleomycin ligand sites on the cell surface has an important role in cellular sensibility to this drug.

It is possible that Ehrlich tumor cells used in this experiment had a larger number of membrane proteins that binds to bleomycin. This could explain percentages of tumor growth inhibition, neoplastic tissue, necrosis and proliferation rate in the Bleomycin group. Besides, it could justify the similarity between Bleomycin and Electrochemotherapy groups. If cells already have an elevated number of transport proteins, opening pores on the membrane would not have a significant effect, as seen with other drugs such as doxorubicin, vincristine and carboplatin (Sersa et al., 2008). More studies are necessary to validate this theory in Ehrlich cells.

\section{CONCLUSIONS}

Within the conditions in which this experiment was conducted, it can be concluded that: The objective of building an electroporator that allows individual parameter programming (i. e. amplitude, frequency, wave polarity) within an operation limit was achieved. Treatment under anesthesia was well tolerated by the animals, with no mortality and minimal weight loss. Electrochemotherapy group animals showed more inflammation, tumor reduction and neoplastic tissue percentage reduction, despite bleomycin route of administration and usage of a tumor model that was not ideal to assess the technique due to low immunogenicity and extensive areas of necrosis. More studies are necessary to evaluate bleomycin transport protein in plasma membrane of Ehrlich tumor cells used in this experiment.

\section{FUNDING}

This article was developed at the Federal University of Minas Gerais on the year 2015 and was financed by the National Counsel of Technological and Scientific Development. 


\section{REFERENCES}

CARRY, P.J.; PRESCOTT, D.M.; OGILVIE, G.K. Resistance to ehrlich ascites tumor in a strain of dystrophic mice. Cancer Res., v.39, p.2139-2140, 1979

CEMAZAR, M.; TAMZALI, Y.; SERSA, G. et al. Electrochemotherapy in veterinary oncology. J. Vet. Intern. Med., v.22, p.826-831, 2008.

ELBIALY, N.; ABDELHAMID, M.; YOUSSEF, T. Low power argon laser-induced thermal therapy for subcutaneous Ehrlich carcinoma in mice using spherical gold nanoparticles. J. Biomed. Nanotechnol., v.6, p.17, 2010 .

ELBIALY, N.S.; MADY, M.M. Ehrlich tumor inhibition using doxorubicin containing liposomes. Saudi Pharm. J., v.23, p.182-187, 2015.

Esope Newsletter n.3. 2003. Disponível em $<$ www.cliniporator.com $>$. Acessado em 24 setembro 2014.

FERREIRA, M.A.N.D. Avaliação da angiogênese, inflamação e crescimento tumoral em camundongos com deleção gênica dos receptores para o PAF (PAFR-KO). 2006. 162f. Tese (Doutorado em Ciências Biológicas) Instituto de Ciências Biológicas, Universidade Federal de Minas Gerais, MG.

GOTHELF, A.; MIR, L.M.; GEHL, J. Electrochemotherapy: results of cancer treatment using enhanced delivery of bleomycin by electroporation. Cancer Treat. Rev., v.29, p.371$387,2003$.

LANORE, D.; DELPRAT, C. (Eds.). Quimioterapia anticancerígena. Rio de Janeiro: Roca, 2004. 179 p.

LARKIN, J.O.; COLLINS, C.G.; AARONS, S. et al. Electrochemotherapy - aspects of preclinical development and early clinical experience. Ann. Surg., v.245, p.469-479, 2007.

MARTY, M.; SERSA, G.; GARBAY, J.R. et al. Electrochemotherapy - an easy, highly effective and safe treatment of cutaneous and subcutaneous metastases: results of ESOPE (European Standard Operating Procedures of Electrochemotherapy) study. Eur. J. Cancer Suppl., v.4, p.3-13, 2006.
MIKLAVCIC, D.; MALI, B.; KOS, B. et al. Electrochemotherapy: from the drawing board into medical practice. Biomed. Eng. OnLine, v.13, p.1-20, 2014.

MIKLAVCIC, D.; SERSA, G.; BRECELJ, E. et al. Electrochemotherapy: technological advancements for efficient electroporation-based treatment of internal tumors. Med. Biol. Eng. Comput., v.50, p.1213-1225, 2012.

MIR, L.M. Bases and rationale of the electrochemotherapy. Eur. J. Cancer, Suppl., v.4, p.38-44, 2006.

MIR, L.M.; GEHL, J.; SERSA, G. et al. Standard operating procedures of the electrochemotherapy: Instructions for the use of bleomycin or cisplatin administered either systemically or locally and electric pulses delivered by the Cliniporator ${ }^{\mathrm{TM}}$ by means of invasive or non-invasive electrodes. Eur. J. Cancer, Suppl., v.4, p.14-25, 2006.

MIR, L.M.; TOUNEKTI, O.; ORLOWSKI, S. Bleomycin: revival of an old drug. Gen. Pharmacol., v.27, p.745-748, 1996.

PEREIRA, B.G.; FIALHO, S.L.; SOUZA, C.M. et al. Evaluation of the effects of thalidomideloaded biodegradable devices in solid Ehrlich tumor. Biomed. Pharmacother., v.67, p.129-132, 2013.

PRON, G.; BELEHRADEK, J.; MIR, L.M. Identification of a plasma membrane protein that specifically binds bleomycin. Biochem. Biophys. Res. Commun., v.194, p.333-337, 1993.

SANTOS, R.G. Projeto e construção de geradores portáteis de pulsos elétricos bipolares de alta tensão para tratamentos de eletroquimioterapia. 2014. 55f. Monografia (Conclusão de Curso) - Universidade Federal de Minas Gerais, MG.

SERSA, G.; CEMAZAR, M.; DAMIJAN, M. et al. Electrochemotherapy: variable anti-tumor effect on diferent tumor models. Bioelectrochem. Bioenerg., v.35, p.23-27, 1994.

SERSA, G.; CEMAZAR, M.; MIKLAVCIC, D. et al. Electrochemotherapy of tumours. Radiol. Oncol., v.40, p.163-174, 2006.

SERSA, G.; CEMAZAR, M.; RUDOLF, Z. Electrochemotherapy: advantages and drawbacks in treatment of cancer patients. Cancer Ther., v.1, p.133-142, 2003. 


\section{Cunha et al.}

SERSA, G.; MIKLAVCIC, D.; CEMAZAR, M. et al. Electrochemotherapy in treatment of tumours. Eur. J. Surg. Oncol., v.34, p.232-240, 2008.

SERSA, G.; MIKLAVCIC, D.; CEMAZAR, M. et al. Electrochemotherapy with CDDP on LPB sarcoma: comparison of the anti-tumor effectiveness in immunocompetent and immunodeficient mice. Bioeleclrochem. Bioenerg., v.43, p.279-283, 1997.

SILVA, M.D. Desenvolvimento e avaliação de um gerador programável depulsos monofásicos de campo elétrico para eletroporação. 2011. 86f. Dissertação (Mestrado em Engenharia Biomédica) - Universidade Federal do Rio de Janeiro, Rio de Janeiro, RJ.
SOUZA, C.M.; FERREIRA, E.; FERREIRA, M.A.N.D. et al. Kint3-4 protein from human plasminogen delays Ehrlich tumor growth in mice. J. Bras. Patol. Med. Lab., v.47, p.465-472, 2011.

TOZON, N.; KODRE, V.; SERSA, G. et al. Effective treatment of perianal tumors in dogs with electrochemotherapy. Anticancer Res., v.25, p.839-846, 2005. 